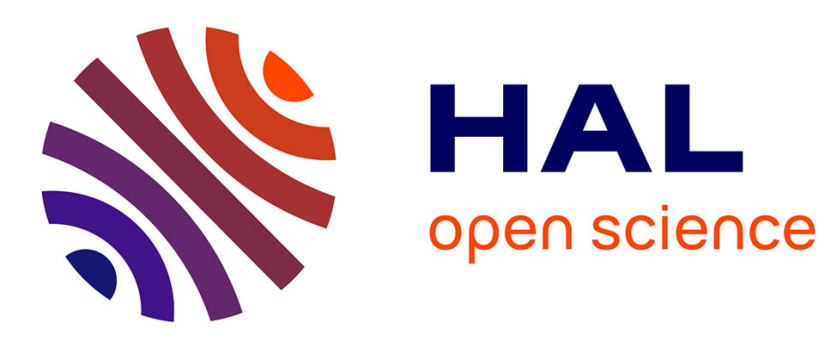

\title{
Alginate-Based Cell Microencapsulation for Tissue Engineering and Regenerative Medicine
}

Vittoria Pandolfi, Ulysse Pereira, Murielle Dufresne, Cécile Legallais

\section{To cite this version:}

Vittoria Pandolfi, Ulysse Pereira, Murielle Dufresne, Cécile Legallais. Alginate-Based Cell Microencapsulation for Tissue Engineering and Regenerative Medicine. Current Pharmaceutical Design, 2017, 23 (26), 10.2174/1381612823666170609084016 . hal-02938367

\section{HAL Id: hal-02938367 https://hal.science/hal-02938367}

Submitted on 11 Dec 2020

HAL is a multi-disciplinary open access archive for the deposit and dissemination of scientific research documents, whether they are published or not. The documents may come from teaching and research institutions in France or abroad, or from public or private research centers.
L'archive ouverte pluridisciplinaire HAL, est destinée au dépôt et à la diffusion de documents scientifiques de niveau recherche, publiés ou non, émanant des établissements d'enseignement et de recherche français ou étrangers, des laboratoires publics ou privés. 


\title{
Alginate-Based Cell Microencapsulation for Tissue Engineering and Regenerative Medicine
}

\author{
Vittoria Pandolfi, Ulysse Pereira, Murielle Dufresne, and Cécile Legallais*
}

Laboratory of Biomechanics \& Bioengineering, UMR CNRS 7338, Université de Technologie de Compiègne, Sorbonne Universités, Compiègne, France

\begin{abstract}
Increasing numbers of requests for transplantable organs and their scarcity has led to a pressing need to find alternative solutions to standard transplantation. An appealing but challenging proposal came from the fields of tissue engineering and regenerative medicine, the purpose of which is to build tissues/organs from scratch in the laboratory and use them as either permanent substitutes for direct implantation into the patient's body, or as temporary substitutes to bridge patients until organ regeneration or transplantation. Using bioartificial constructs requires administration of immunosuppressant therapies to prevent rejection by the recipient.

Microencapsulation has been identified as promising technology for immunoisolating biological materials from immune system attacks by the patient. It is based on entrapping cellular material within a spherical semipermeable polymeric scaffold. This latter defines the boundary between the internal native-like environment and the external "aggressive" one. The scaffold thus acts like a selective filter that makes possible an appropriate supply of nutrients and oxygen to the cellular constructs, while blocking the passage for adverse molecules. Alginate, which is a natural polymer, is the main biomaterial used in this context. Its excellent properties and mild gelation ability provide suitable conditions for supporting viability and preserving the functionalities of the cellular-engineered constructs over long periods. Although much remains to be done before bringing microencapsulated constructs into clinical practice, an increasing number of applications for alginate-based microencapsulation in numerous medical areas confirm the considerable potential for this technology in providing a cure for transplant in patients that excludes immunosuppressive therapies.
\end{abstract}

A R T I C L E H I S T O R Y

Received: April 24, 2017 Accepted: June 1, 2017

DOI: $10.2174 / 1381612823666170609084016$

Keywords: Tissue engineering, regenerative medicine, encapsulation, alginate beads, transplantation, extracorporeal supply.

\section{INTRODUCTION}

The growing demand but insufficient availability of transplantable organs for the enormous number of candidates on waiting lists (about 119,712 in the current year according to the data reported by the United Network for Organ Sharing) was the primary motivation for scientists to find alternative permanent or temporary therapeutic treatments in order to guarantee patient survival. In the last thirty years, tissue engineering and regenerative medicine have taken up the cause; these research fields have suggested creating tissue constructs in the laboratory so that these constructs can replace the native organ's failing functions once implanted into the body [1]. Considerable effort has also been made to develop extracorporeal support systems (e.g., bioartificial livers and kidneys) which, thanks to the presence of cells, could bridge patients until organ regeneration or transplantation $[1,2]$. Like standard organ transplantation, these strategies involve using life-long immunosuppressant therapies to prevent an immune response in the host body and the subsequent rejection of the bioartificial constructs. Long-term administration of immunosuppressants is, unfortunately, associated with serious side effects, including kidney failure, and, therefore, needs to be decreased or replaced.

In this context, cell microencapsulation has been proposed as effective technology for immunoisolation of biological material to avoid immune suppression and overcome a host immune response in therapeutic applications [3-8]. It consists of enveloping viable and functional cells within a spherical semi-permeable scaffold that provides a suitable inner microenvironment to maintain the cells' physical and functional integrity while protecting them from

*Address correspondence to this author at Laboratoire Biomécanique \& Bioingénierie, Université de Technologie de Compiègne, Sorbonne Universités, 60203, Compiègne, France; Tel/Fax: +33 3442346 70;

E-mail: cecile.legallais@utc.fr external attacks. The scaffold is generally made of a polymeric biomaterial, either of natural or synthetic origin, that must have high biocompatibility and biotolerability, and contain no or minimal amounts of endotoxins [9]. Natural polymers are the most suitable choice for this application. This is especially due to their structure, that is similar to the extracellular matrix of many human tissues, and their composition, that is made of macromolecules similarly present in biological environments of the body [10]. Although several biomaterials have been assessed (including agarose, chitosan, hyaluronic acid, collagen, and fibrin [10]), alginate easily satisfies the above-mentioned prerequisites and, consequently, is the most commonly used polymer in this context $[9,10]$. In addition, the scaffold must have well-designed physical characteristics (including shape, size, and porosity) that make possible a rapid exchange of nutrients and oxygen between the surroundings and the cells, as well as the transfer of cellular therapeutic products in the opposite direction. A spherical shape, such as beads or capsules, is preferred over other geometries because it offers the best surface-to-volume ratio, responsible for the most efficient mass transfer of the molecules between in and out compartments $[11,12]$.

This review proposes an analysis of some major areas of application for alginate-bead cell microencapsulation in tissue engineering and regenerative medicine. The subjects are introduced by an overview of alginate material and its features in order to better understand the advantages of using it in this field.

\section{ALGINATE: A GOLD-STANDARD BIOMATERIAL FOR CELL MICROENCAPSULATION}

Alginate is the most commonly-used biomaterial for cell microencapsulation $[10,13]$. It is considered the main encapsulation polymer for clinical applications and is the only encapsulation matrix that has been approved for human use by the U.S. Food and Drug Administration (FDA) [14]. Its excellent physical-chemical 
characteristics inevitably play a part in this success. Alginate has a low gelling capability, is easy to handle and biocompatible, has low toxicity, good in vivo performances $[10,13,15,16]$, and, last but not the least, low endotoxin lipopolysaccharide content [9].

Alginate is a naturally occurring unbranched anionic polysaccharide that is generally extracted from brown algae (Phaeophyta), but can also be synthesized by bacteria (Azotobacter and Pseudomonas) [17]. Alginate is formed by linear copolymers containing blocks of $(1,4)$-linked $\beta$-D-mannuronate $(\mathrm{M})$ and $\alpha$-L-guluronate (G) residues. The $\mathrm{G}$ and $\mathrm{M}$ residues can arrange themselves in consecutive (GGG and MMM) and alternating (GMGM) order in the blocks. However, the content of $M$ and $G$ residues, the $M / G$ ratio and their arrangement depend particularly on the natural source from which the alginate is obtained. Along with G-block length and molecular weight, these are critical parameters. They not only affect the physical properties of alginate and its resultant hydrogels [18], but also play a role in the body's inflammatory response and fibrotic overgrowth after implantation [19]. In turn, the physical features of alginate hydrogels influence the biochemical responses of the encapsulated cells. For instance, it has been widely proven that alginates, rich in $\mathrm{G}$ residues, hinder the growth and metabolic activity of the cells, unlike alginates rich in M residues [20-23].

\subsection{Biocompatibility}

Alginate biocompatibility has been well-documented both in vitro and in vivo. This feature is strictly dependent on purification of the alginate which, accordingly, is an essential step for using the polymer in biomedical applications. Raw alginate, although low in endotoxin lipopolysaccharide content [9], nevertheless has various other impurities, including lipoteichoic acids and proteoglycans [9], which are responsible for activating pro-inflammatory responses and, consequently, compromising the biocompatibility of the construct $[9,13,16,24]$. In case of implantation, for instance, these processes lead to the failure of the graft with overgrowth of the fibrotic capsule around it, impeding cell nutrition and causing necrosis of the enveloped cells [19].

Several purification procedures have been proposed in different laboratories [25-27]. These are basically based on filtration and charcoal treatment, protein extraction, and precipitation steps. There is evidence that the methods established in various laboratories provide different results [28]. Standardized protocols are therefore required in order to obtain suitable batches of purified alginates with similar characteristics $[13,24]$. In 2003, Orive et al. expressed the idea of setting up a 'central alginate factory' that could prepare standardized prototypes for use by participating laboratories in their transplant studies [24]. Further strategies have been proposed to improve the biocompatibility of cell-encapsulated alginate microspheres; these include traditional approaches of temporarily administering immunosuppressants $[14,23,24]$ and modifying the surface properties by adding chemical groups [25-27], as well as relatively new methods that involve binding long stretched molecules, socalled polymer brushes, with high density on an identical surface area of the microspheres so that they can prevent protein adhesion [28-31].

\subsection{Alginate Bead Fabrication and Cell Loading}

Alginate has the ability to polymerize. Its gelation process simply occurs at a mild $\mathrm{pH}$, temperature, and salt conditions that slightly affect cell viability. In principle, adjacent alginate chains bind in the presence of divalent cations (e.g. $\mathrm{Ca}^{2+}$ or $\mathrm{Ba}^{2+}$ ), forming ionic interchain bridges [10]. Due to the different affinities of alginate for divalent cations, choosing the latter influences the physical properties of the resultant alginate gel (e.g. mechanical strength) [29]. Cell loading normally occurs prior to gelation; that is, cells are first suspended in a water-based alginate solution and, upon exposure to the cations, are then entrapped within the crosslinked alginate network [30].
Alginate beads are manufactured with respect to the basic principle given above, with the addition of technical procedures which make it possible to build the rigid spherical shape. These methodologies are more often involved in the extrusion of the cell-alginate solution through a syringe needle into a gelling bath. The droplet immediately polymerizes when surrounded by cations, but maintains its spherical shape (Fig. 1).

Extrusion is the simplest method for producing large-sized alginate beads (millimetric order). To create micron-sized spheres, which are more suitable for cellular applications, external forces (such as electric fields, mechanical vibration, and air flow) must however be applied, so that the extruded alginate can be broken up into small, size-tunable droplets $[10,31]$. Microbeads effectively have improved characteristics, such as a higher exchange rate for substances between cells and the external environment, high mechanical resistance, and a milder pericapsular reaction once implanted [10]. More sophisticated technologies have recently been introduced in order to better control the encapsulation parameters (including cellular density, the homogeneity of bead dimensions and reproducibility); these are based on cutting-edge microfluidic platforms [10, 32-34] and bioprinting [10,35].

\subsection{Multilayer and Covalent Cross-Linking Strategies}

Although alginate beads are easy to manufacture, tuning their final properties requires several optimization steps in the manufacturing process. Multilayer and covalent cross-linking technologies are commonly used strategies that, of all the others, make it possible to conveniently manipulate the features of alginate microbeads, such as permeability or (mechanical) stability. These latter, together with biocompatibility, are considered important characteristics of the beads and effectively influence the success of the final construct. Modifications - made on the basic structure of the alginate beads - often affect both permeability and (mechanical) stability. However, it is still very challenging to reach perfect tuning of both features by modifying a single physical characteristic of the alginate beads. Ideally, an optimal compromise between mechanical strength and mass transport needs to be found to guarantee the preservation of cell functionalities [8].

The need to adjust the permeability of "nude" alginate beads derives from the limited tuning of their cutoff, which does not make possible total control of the traffic of adverse molecules. In addition to therapeutic molecules, encapsulated cells in fact release antibodies and cytokines. These factors are actively involved in the activation of macrophages and trigger fibrosis processes, which are mainly involved in the failure of the construct. Antibodies are efficiently blocked by the alginate barrier, contrary to cytokines which, being of similar size to beneficial molecules (e.g. insulin), cannot be prevented from crossing the polymeric boundary. The motion is equally unregulated in the opposite direction, and can cause as many undesirable effects. Applying multilayers on top of microbeads resulted in offering the most adequate regulation of substance selection [19]. The strategy also exhibited great potential for improving the surface finish of the beads so as to prevent fibroblast adhesion [36] which can also be an explanation for the fibrosis [37]. Similarly, applying multilayers to the surface of alginate beads prevented cell protrusion; this undesirable phenomenon has been accused of inducing fibrotic reactions and, consequently, determining rejection of the construct $[11,38]$. Depositing multilayers on to the surface of alginate beads is commonly made possible by the layer-by-layer technique [39]. This is an easy and cheap method that consists in attaching highly and oppositely charged polyions on to charged surfaces in a self-assembly process [19]. A consistent number of coatings have been assessed so far [40-43]. However, polycations, such as poly-L-lysine and poly-L-ornithine, are the most widely-used in this context. On the contrary, polycationic coatings show a huge variety of drawbacks. Although polycationic coatings determined the reinforcement of alginate beads and de- 


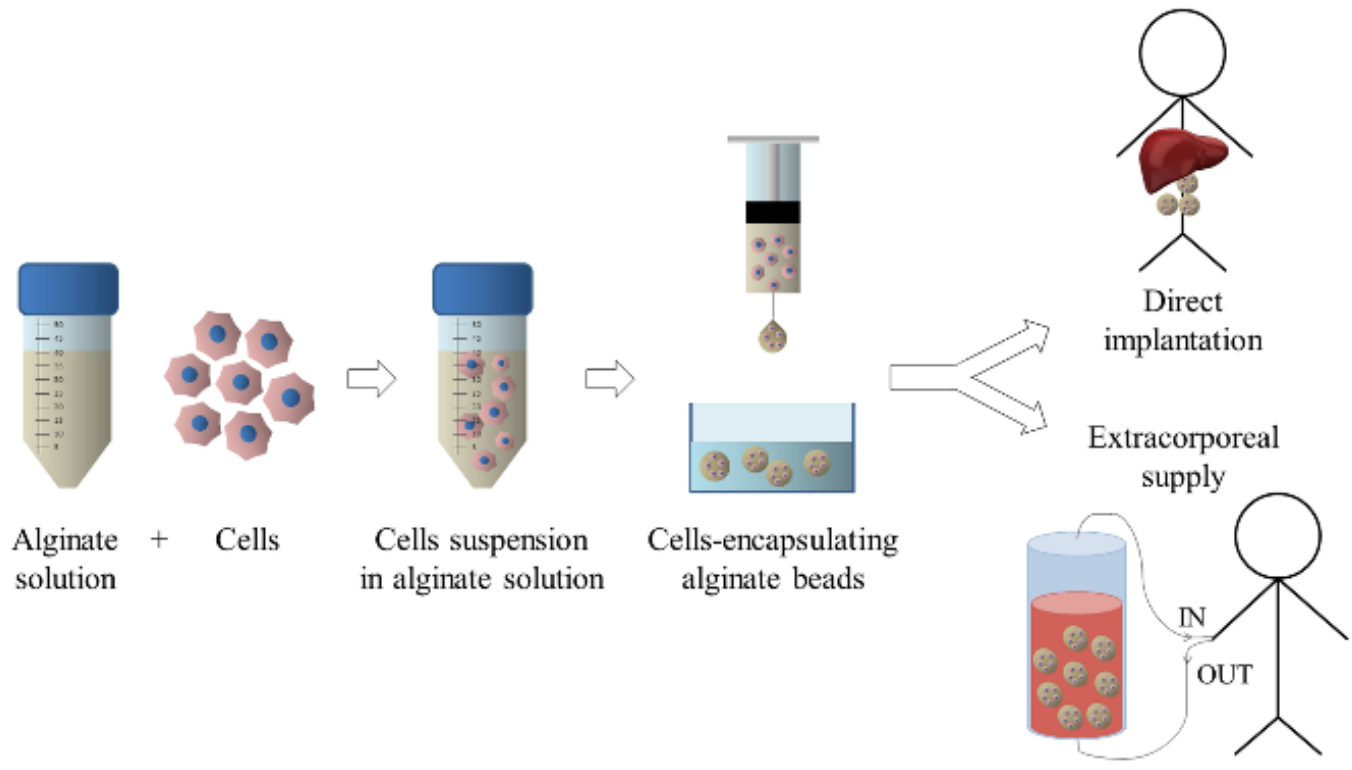

Fig. (1). Representative diagram of the microencapsulation process: from manufacture of the cell-encapsulating alginate beads to their application as direct implants in several body sites or as temporary substitutes in extracorporeal devices.

creased their permeability to the host's immune cells and antibodies [44], they lack sufficient mechanical strength, biocompatibility, and long-term stability in vivo [8]. More importantly, they are often a frequent cause of inflammation $[45,46]$ and fibrosis because they attract macrophages and/or detach from the alginate bead surface $[8,47]$. A common solution was to cover the polycation layer with a second alginate coating. However, this risked reducing membrane permeability and correct oxygen and nutrient supply to the cells. Furthermore, the outer alginate layer does not provide efficient results for completely neutralizing the polycation layer, avoiding protein and cellular adhesion and the consequent induction of fibrotic processes [44]. New strategies have recently been proposed as alternatives to the current polycationic coatings. Protamine and cationized potato starch are two examples of new coatings which, in addition to controlling the permselectivity of the beads, demonstrated a promising ability to improve survival [48] and preserve the metabolic activities of the encapsulated cells [49] in comparison with classical polycations.

Most of these strategies do not vary the ionic bridges present between adjacent chains in the internal structure of the alginate beads, as established during their standard polymerization thanks to the inclusion of divalent cations. Ionically-bonded alginate beads nevertheless suffer from very low mechanical and chemical stability in physiological solutions and within the implantation sites of the body; this aspect gives rise to a series of phenomena ending with the rupture of the beads $[8,50]$. Covalent cross-linking strategies have thus attracted substantial attention for the manufacture of long-term resistant alginate beads. Photoinitiated polymerization is one of the most commonly-adopted techniques for forming covalently cross-linked gels. In general, polymerization occurs by rapidly exposing the biomaterial and suitable initiators to UV or visible light; the cells and bioactive molecules can already be present in the biomaterial. The final mechanical properties can easily be tuned by changing the degree of photo-curable moiety [8]. Covalent alginate beads can also be obtained by adding phenol moieties into the polymer side chains and establishing alginate-tyramine conjugates. The gelation takes place in the presence of $\mathrm{H}_{2} \mathrm{O}_{2}$ and horseradish peroxidase and it is almost instantaneous (seconds). The resulting alginate beads manifest high cytocompatibility and mechanical strength [8]. In another study, human hepatocellular carcinoma cells
(Huh7) were successfully encapsulated in calcium alginate poly(ethylene glycol) forming hybrid microspheres (Ca-alg-PEG). Grafting some percents of the backbone units of sodium alginate (Na-alg) with -amine- -thiol PEG maintained the gelling capacity in the presence of calcium ions, while thiol end groups made it possible to prepare chemically crosslinked hydrogels via spontaneous disulfide bond formation [51]. Additional advanced methods are currently under investigation. An energy dissipating mechanism, for instance, is an appealing alternative to improve the cell microencapsulation field. It consists in promoting the formation of hydrogels with a hybrid backbone, where ionic cross-linked alginate chains are covalently linked to covalent cross-linked chains of polyacrylamide gels [52]. The final construct has excellent mechanical properties.

\section{CELL MICROENCAPSULATION FOR APPLICATIONS IN TISSUE ENGINEERING AND REGENERATIVE MEDI- CINE}

The concept of cell encapsulation applied in the medical field was introduced in 1933, when Bisceglie et al. [53] enveloped tumor cells in amnion tissue-sheets to study the effect of the absence of vascularization on tumors. The construct, when implanted into the abdominal cavity of pigs, maintained cell survival for extended time periods, which was probably a beneficial consequence of the immunoprotection from the host environment provided by the membranes. However, the group did not recognize the potential of this technology, so it was not exploited for the treatment of diseases. It was only in 1950 that the concept of immunoisolation started to acquire importance in the context of the implantation of biological material for therapeutic purposes [54]. Fourteen years later, Chang [55] formalized the need to use ultrathin polymer membrane microcapsules for the immunoprotection of transplanted cells; eventually, this introduced the concept of bioencapsulation. The real breakthrough came with Lim and Sum [56] who were the first to demonstrate the effectiveness of the technology. In their studies, pancreatic islets were encapsulated in polyanionic alginate beads coated with a polycationic poly(L-lysine) layer, and then implanted into chemically-induced diabetic rats. The new microencapsulation procedure actually reduced the problem of immune rejection, making possible long-term maintenance (over 15 weeks) of the cells' morphology and functionalities. 
Since then, cell microencapsulation technology has obtained considerable attention from the scientific community, extending its application to an increased range of therapeutic areas. The potential of this technique has been demonstrated in different in vitro investigations and pre-clinical studies. In some medical fields, it has already been evaluated in preliminary clinical trials. So far, the results of these studies have shown the safety, feasibility, and tolerability of this therapeutic approach [8]. However, there are still many limitations, especially associated with the wide variability in cell survival (from days to years) in the encapsulated environment [8]. The challenge has thus been to further improve the cell microencapsulation procedure in order to define routine clinical practices, different for each therapeutic application, and thus minimize errors.

Of the many of medical fields involving the application of cell microencapsulation, three areas of interest are reviewed below. The idea here is to provide readers with an overview of the current situation, allowing them to understand the growing importance attributed to microencapsulation over the years. Thus, to delineate the time evolution of this technology, our topic selection includes (i) the bioartificial pancreas, where cell microencapsulation found its first application and, accordingly, has developed rapidly; (ii) hepatic substitutes, whose investigation highlights the crucial benefits of using cell microencapsulation in both grafting and bioartificial extracorporeal devices; and (iii) stem cell differentiation, which is a relatively recent and only partially explored application area for microencapsulation.

\subsection{The Bioartificial Pancreas}

The pancreas is a fundamental organ involved in the regulation of the body's metabolism through the production of a variety of hormones. The release of these molecules is carried out by clusters of four different cell types (alpha and beta, which are respectively $20 \%$ and $50 \%$ of the total islet cells, delta and gamma cells), called islets of Langerhans. Beta $(\beta)$ cells are the components responsible for the secretion of insulin; this latter is released in proportional response to actual blood glucose levels and promotes its uptake (mainly in the liver) making it possible to control blood glucose homeostasis. Inefficient pancreatic $\beta$ cell function thus determines persistent hyperglycemia; the resulting chronic disorder is wellknown: diabetes. In this condition, either $\beta$-cells are unable to fulfill their tasks because they are completely destroyed by the immune system (type-1 diabetes), or they gradually stop functioning (type-2 diabetes) due to their excessive solicitation as a result of genetic and environmental factors. Besides exogenous insulin injection therapy, $\beta$-cell transplantation offers an improved therapeutic solution for type-1 diabetic patients, especially for those whose blood glucose levels are difficult to control despite intensive insulin doses [57], guaranteeing normal stimulus-coupled insulin secretion kinetics. This procedure, however, has certain limitations, including host rejection of the graft in the absence of immunosuppression.

\subsubsection{Bead Composition}

Alginate microencapsulation of Langerhans islets, which corresponds with the bioengineering approach to design a bioartificial pancreas, has been shown to be a relevant solution to the immunorejection of the graft [58]. As already mentioned, the technique was first introduced by Lim and Sum [56]; then, considering their promising results on transplanted diabetic rats, numerous other studies followed. For about two decades, chemically-induced and spontaneous diabetic animal models (rodents, canines, and primates) made it possible to explore several parameters and criteria for the definition of a system that could maintain its characteristics and functionalities in the long term [59-68]. Great attention has been paid to the manufacture of alginate beads to allow them to offer cells a biocompatible environment, minimize inflammatory processes upon implantation, and manifest enhanced stability over time. Alginate does not support interactions with cells [69]. This aspect is nevertheless crucial in prolonging cell survival within the microbeads after transplantation. Accordingly, the usual inclusion of arginine-glycine-aspartic acid (RGD) sequences in the alginate backbone has been proved to beneficially affect the long-term maintenance of functional and viable grafts in both small and large animals $[60,70]$. At a more complex level, a porcine pancreatic extracellular matrix (ECM), obtained from a decellularized organ via ECM lyophilization and liquefaction stages, has recently been crosslinked within poly-L-lysine coated alginate beads [71]. Implantation of the resulting microbeads, encapsulating non- $\beta$ insulinsecreting cells, in diabetic mice produced a promising outcome; in fact, despite the low density of encapsulated cells, the system promoted increased insulin secretion and good maintenance of glucose levels. An appropriate internal environment can, however be compromised if it is not protected from outside attacks. For certain scientists, outer alginate coatings have become mandatory for permselecting external elements. For this reason, several types of polyamine coatings have been evaluated by several researchers; however, most of these were found to strongly induce the host inflammatory response [45, 72]. In 2006, Ponce et al. [73] proposed polyL-lysine as the optimal coating for reducing host reactions. Previous studies highlighted that selecting an alginate bead crosslinking bath was paramount for permselectivity; the barium bath improved the alginate features compared to calcium [74]. In these circumstances, polyamine coating did not result necessary. However, ionically-bonded alginate hydrogels lack the mechanical stability to support the strains associated with implantation and, therefore, they degrade and rupture easily due to the exchange of cations with sodium ions in the in vivo environment $[75,76]$. Methods for forming covalent bonds within the alginate beads have thus been developed to enhance their stability. Photo-crosslinking is probably the most common technique used to form covalent bonds in the alginate backbone in the presence of photopolymerizable groups, such as methacrylate groups [77-85]. Although this process gives the alginate beads high stability and increased mechanical strength, it generates free radicals that cause significant cell toxicity. Of the alternative strategies, Hall et al. [50] engineered polymers capable of forming spontaneous, covalent linkages. The resulting microbeads, obtained through ionic and covalent interactions between functionalized alginate and poly(ethylene glycol) polymer, presented high levels of stability and high cell compatibility.

\subsubsection{Preclinical studies}

In all these studies, the overall condition of the animal transplanted with microbeads was positive. Microencapsulated islets were well-protected from the outside environment in the animal's implantation site, unlike the non-encapsulated islets that were rejected a few days after transplantation. Accordingly, cells were healthy and functional in the beads, determining, in most cases, normoglycemia of the diabetic animal for several days (the duration was very variable between the different studies). In cases of severe hypoxia, which is a major contributor to the dramatic drop in $\beta$ cell viability after transplantation, microencapsulated islets also remained alive and functional when entrapped in alginate beads; it was thus suggested that these latter could prevent islet destruction by playing a protective role in cases of hypoxia [86]. However, the response to the treatment was very dependent on the type of transplanted animal, the source of the islets, and the implantation site. In fact, great success in rodents, dogs, and pigs often corresponded to failures in other large animals [87]. The animal's posture was found to have a significant influence on the final behavior. While this therapy resulted in well-fixed allocation of the microbeads within the intraperitoneal site in quadrupeds [88], the results were remarkably variable in biped non-human primates [3, 88-94]. The results were associated with the strength by which the microbeads adhered to the implantation site, preventing them from falling into the pelvis or not. Implantation site has also been a critical subject of investigation due to its influence on the stability and biocompatibility of microencapsulated islets. Subcutaneous sites have many po- 
tential strengths, including their large capacity, the convenience of minimally-invasive implantation procedures, and the simplicity of monitoring the graft. Nonetheless, Kerby et al. [95] negatively referred to it. Alginate microencapsulated islets transplanted subcutaneously were not in fact able to reverse the diabetic state of the mice. This limited success was also highlighted elsewhere [96-98]. Several other implantation sites have been assessed in pre-clinical studies (kidney capsule, bone marrow, and omentum); however, intraperitoneal implantation has been considered to be the most adequate as it has made it possible to restore normoglycemia [99, $100]$. Accordingly, this is the site used primarily in clinical investigations.

In short, animal pre-clinical studies have mainly demonstrated full safety and the functional performance of alginate microencapsulated allogeneic and xenogeneic islets upon implantation. Preclinical outcomes were, therefore, sufficiently successful to allow some worldwide research centers to obtain authorizations to proceed with phase I/II clinical trials of alginate encapsulated islets implanted into type 1 diabetic patients. The studies are recent, having started just ten years ago.

\subsubsection{Clinical Studies}

The first records go back to 2005 when Calafiore et al. [92, 101] were granted permission to transplant ten nonimmunosuppressed patients with long-standing type 1 diabetes and cured with intensive insulin therapy regimens. The patients were grafted intraperitoneally with human allogeneic islets microencapsulated in ultra-purified alginate- poly-L-ornithine -alginate. Two of them received multiple subsequent grafts in better-vascularized sites (i.e. mesentery). Patient follow-up lasted for different time periods and the results are so far available for only some of them $[44,102]$. In general, excellent reactions to the transplantation procedure and an absence of immune response were observed in all cases. Significantly, the daily exogenous insulin dose was reduced in all treated patients and suspended for one of them. However, these metabolic improvements were temporary ( 6 months up to 1 year) and obliged the patients to return to normal insulin injections at the end of 5 years of treatment. In conclusion, alginate-poly-Lornithine-alginate confirmed its ability to protect allogeneic cells from the recipient's immune system attack and its long-term safety (in patients monitored for 4 years); nevertheless, the encapsulation strategy was not sufficiently optimal to make possible long-term preservation of functional islets.

In 2007, Living Cell Technologies suggested implanting porcine islets encapsulated in alginate-poly-L-lysine-alginate into the intraperitoneal site of a 41-year-old man [103]. Surprisingly, the results were better than expected because the treatment promoted a reduction in exogenous insulin injections and, unlike the previous trial, 10-year maintenance of cell survival. Moreover, the safety of the encapsulation strategy was validated as porcine viral and retroviral infections were not detected. Two years later, the company decided to launch a phase I/IIa study in Moscow. Microencapsulated neonatal insulin-producing porcine pancreatic islet cells were implanted, in a unique or multiple injections, into seven insulindependent diabetic patients [102]. The results were promising: the procedure was well-accepted by the patients and their diabetes was better controlled. Phase IIb clinical trials have thus been recently launched in New Zealand and Argentina.

In 2009, another phase I clinical study was carried out by Tuch and his team in Australia [4]. Human islets were encapsulated in barium-alginate microbeads and intraperitoneally implanted into four patients. Transplantation was performed according to different grafting schedules in the four patients: one of them underwent four islet infusions over seven months, another patient had two transplantations ten months apart, and the remaining two were grafted only once. In all cases, anti-inflammatory and anti-oxidant therapy was provided after transplantation. Nonetheless, the microencapsu- lated islets did not result in substantial improvements. Insulin production was not enough to control the glycemic levels in the patients' blood. The implants were thus removed to figure out the cause of the problem. The beads were found stuck to several tissues in the peritoneal cavity and enveloped in fibrotic capsules. This latter was blamed as the major cause of cell necrosis and loss of graft function.

A recent clinical study ended with similarly negative results [104]. Human islets microencapsulated in barium-calcium alginate were implanted in a 61-year-old female immunosuppressed patient, previously grafted with a whole organ. In this case, it was not possible to reduce daily exogenous insulin therapy even in the three months following transplantation. The detection of diabetes autoantibodies thus obliged the researchers to retrieve the beads, which were found in the presence of inflammatory tissue.

In conclusion, these preliminary clinical trials have confirmed the potential ascribed to islet microencapsulation technology and its resulting positive outcome in terms of safety. However, these results could not be effectively exploited because of the lack of reproducibility in the different centers. It is clear that further attention still needs to be given to certain critical technical aspects involved in the production of alginate beads [102]. This would make it possible to establish general optimal criteria for providing ultrapure alginate beads that, whether coated with polyamines or not, could be well-tolerated by recipients. The size and morphology of the beads needs to be carefully designed in order to improve functional performance (smaller size) and minimize the risk of macrophage signaling (smooth surface and absence of cell protrusion). The choice of implantation site perhaps requires additional revision so that the high oxygen requirements of pancreatic islets can be better fulfilled and their functionalities preserved longer.

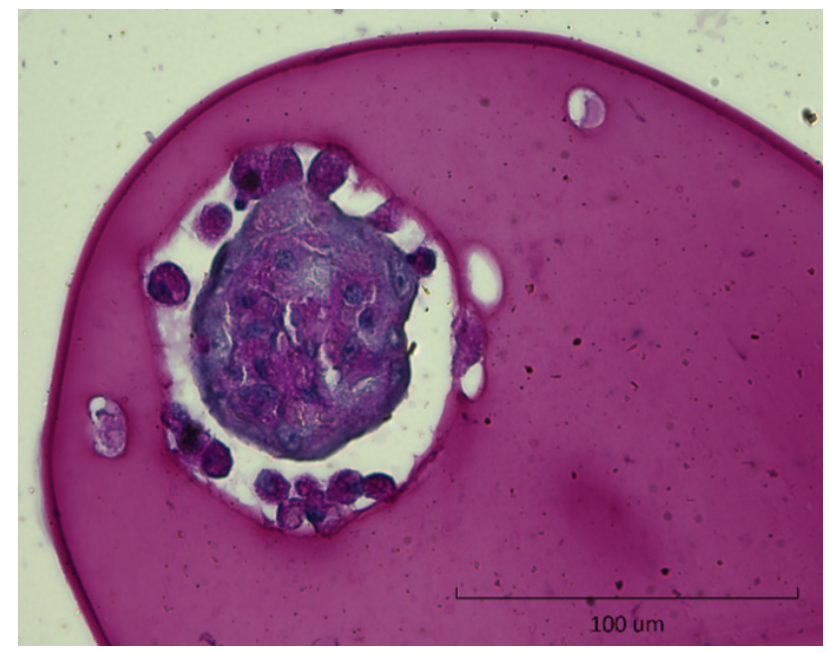

Fig. (2). Hepatic spheroid encapsulated in an alginate bead. The spheroid was formed by the aggregation of hepatocytes and hepatic non-parenchymal cells. The image shows PAS staining that indicates cellular glycogen storage.

\subsection{Hepatic Substitutes}

Tissue engineered livers are the only alternative treatment to transplantation in cases of severe liver failure. Of the different approaches developed so far, hepatocyte microencapsulation lead to either a short-term treatment, if used in an extracorporeal circuit, or a long-term treatment if implanted.

Different cell sources and materials have been investigated since the pioneering work by Dixit et al. (1992). Focusing only on alginate-based materials, the encapsulated cells used are mainly of primary murine [105-120] or porcine [121-125] origin or from hu- 
man cell lines [51, 112, 126-138], the most popular being HepG2/ C3A. Very few studies have reported the encapsulation of primary human hepatocytes [139-142]. This is likely associated with the inability of the primary human hepatocytes to preserve their phenotypes and biological functions in in vitro culture conditions. Cocultures of hepatocytes with different types of feeder cells (derived or not from the liver, primary or cell lines) have alternatively been proposed as a platform for preserving in vitro viability and functionalities of the hepatocytes. However, their encapsulation in alginate beads remains sporadic and investigated little [33, 143, 144]. We recently encapsulated aggregates of primary rat hepatocytes and hepatic sinusoidal non-parenchymal cells (endothelial cells, Kupffer cells, and hepatic stellate cells) in alginate beads (Figure 2). Several primary hepatic activities were analyzed in order to investigate the impact of both non-parenchymal cells and the microenvironment offered by the alginate bead on maintaining in vitro hepatic functions.

\subsubsection{External Bioartificial Liver (BAL)}

In acute liver failure, it is considered that temporary support may be enough to bridge patients until transplantation or to allow the liver to regenerate. An extracorporeal supply with an efficient hepatic biomass thus appears to be the best option, mimicking the treatment proposed by hemodialysis or hemofiltration in kidney replacement. External bioartificial livers generally rely on an extracorporeal circuit, usually composed of a plasmapheresis stage (primary loop) and a secondary loop where additional compounds, such as charcoal or ion exchange column and oxygenator, could be added to the bioreactor hosting the cells $[145,146]$.

Alginate beads hosting hepatic cells can be considered as the solid fraction of a biphasic compound, the fluid fraction being the patient's plasma. The number of cells requested to fulfill liver functions out of the body is still under question, but a range of 15 to 30 $\%$ of a whole liver is generally accepted by the scientific and medical community. This means that about $1 \mathrm{~L}$ of alginate beads with a cell density of several million per $\mathrm{mL}$ of alginate (before the gelling step) should be prepared and then perfused in an adapted bioreactor. In 1999, Doré et al. [147] proposed the concept of a fluidized bed to perfuse the beads in a bioreactor. Based on bioreactor design, adequate perfusion conditions led to permanent motion of the beads in a defined volume and promoted interactions and exchanges between solid and liquid phases [148]. Stable bed expansion with homogenous mixing could be obtained by applying well-defined hydrodynamic conditions [127]. The most advanced progress with this technique led to the definition of a whole circuit hosting either HepG2 [149] or potentially other hepatic cells such as primary human cells [138].

\subsubsection{Implantation of Microencapsulated Hepatic Cells}

As with islet implantation, liver cell microencapsulation was proposed as an alternative to directly injecting hepatocytes into specific sites in the patient's body, enhancing cell functions and ensuring immunoisolation, specifically for xenografts $[115,150]$. In addition to the liver, the spleen or intraperitoneal cavity can accommodate a large number of cells. Several in vivo studies with Gunn rats (hyperbilirubinemia model) $[151,152]$ or rats with induced acute liver failure $[114,116,125]$ have shown positive results regarding cell functions and animal survival.

Several methods have also been proposed to maintain the specific function and phenotype of the bioencapsulated hepatocytes, such as co-encapsulation with other types of cell. The superiority of encapsulated rat hepatocytes mixed with human fetal liver stromal cells engineered to produce bFGF has recently been demonstrated in the treatment of acute hepatic failure in mice [113]. Liu and Chang et al. [153, 154] reported that hepatocyte viability can be maintained longer when encapsulated with mononuclear cells, including stem cells from bone marrow cells. In addition, transplantation of both co-encapsulated cell types improved the ability of the hepatocytes to correct congenital hyperbilirubinemia in Gunn rats during the period of 3 to 10 weeks post-transplantation. These results were confirmed recently by Shi et al. with coencapsulated hepatocytes and bone marrow mesenchymal stem cells in a rat model of acute liver failure [118].

The long-term maintenance and efficacy of microencapsulated hepatocytes depend on the graft site, the potential neovascularization of the implant and the type of cell to be immobilized, and the cytokines and antigens that are secreted. Attempts have been made to prevent an initial host immune-inflammatory response and favor the establishment of tolerance with time-released immunosuppressive drugs or antibody treatment [155]. Another way of further improving implant biocompatibility and nutrition of the encapsulated hepatic cells would be to promote vascularization around the encapsulated cells [156]. This is not straightforward because alginate is inert and, as already stated, does not promote cell adhesion.

Very recently, and for the first time, human hepatocytes have been administered in a clinical study with encouraging safety [141]. Their efficiency was demonstrated in a rat model [142]. These findings suggest the potential of encapsulated hepatocyte transplantation in treating liver failure and, particularly, using stem cell microencapsulation as a new alternative to hepatocytes.

\subsection{Stem-cell Differentiation}

The shortage of transplantable organs also coincides with the issue of low availability of suitable cells, which are often not enough to engineer cellular substitutes capable of recovering the functionalities of a damaged organ. The need to find alternative cell sources has, therefore, become primordial and stringent. The opportunity arose from the high availability of stem cells. These latter, which are unspecialized cells, present the ability to self-renew and to differentiate into specialized cell types through specific development pathways $[157,158]$. Stem cells are categorized according to their origin in embryonic or postnatal/somatic/adult [159] that, in addition, show different differentiation potentiality. Embryonic stem cells are, in fact, totipotent and, therefore, able to generate all types of cells. Instead, postnatal/somatic/adult stem cells can be pluripotent (able to generate all types of cells except cells of the embryonic membrane) or multipotent (able to differentiate into more than one mature cell) $[159,160]$. Over the last decade, it has been firmly demonstrated that the extraordinary features of pluripotency can be induced in adult cells using four embryonic transcription factors, creating so-called induced-pluripotent stem cells [161, 162]. Accordingly, the paramount role of both stem cells (SCs) and induced-pluripotent stem cells (iPSCs) has been corroborated in the field of the regenerative medicine. It is clear that SCs and iPSCs have different cellular portfolios; however, the potential associated with these cells is huge. They may, in fact, be a real breakthrough in the current situation by representing an unlimited in vitro source of cells for in or ex vivo applications. However, there are still many limitations associated with the different types (from the lack of reproducible differentiation protocols to ethical problems).

Increasing understanding of SC behavior has highlighted the fundamental importance of designing a biologically-inspired in vitro cellular microenvironment to guide their growth, differentiation, and functional assembly [163]. Biomaterial scaffolds and bioreactors are paramount tools in this engineering process [164]. As already mentioned, the scaffold generally supports cell survival and function by means of a plethora of chemical and biophysical cues. Cell-cell and cell-matrix interactions, which are most easily established within cell-embedded three-dimensional structures, are mainly involved in SC differentiation $[165,166]$. The alginate beads have been referred to as simple bioreactors; they in fact favor the assembly of a scalable number of undifferentiated SC bodies [167] and make them ready to differentiate into specific cellular lineages [168]. The alginate beads thus identified a method for synchronizing the SCs: these SCs were then able to expand within the 
beads without differentiating, and, when desired, started the differentiation process under specific conditions [169]. Thanks to their egg-box-like microstructure, alginate beads not only offer SCs a niche-like microenvironment [170], which can recover the phenotype of a specific cell lineage [171], but also act as a shield and protection for the SCs against native immunological responses and external mechanical forces and frictions (especially due to in vitro pre-differentiation steps in bioreactors) [172]. However, the advantages of using alginate beads in this context were not only associated with the aspects described above, but also with the possibility of easily scaling up SC production and recovering the differentiated cells, when necessary, by means of simple depolymerization techniques $[169,173]$.

\subsubsection{In vitro Cell Differentiation}

Microencapsulation of SCs has mostly been performed in vitro so far [174-184]. The investigations have shared similar research plans, that is, direct SC differentiation in alginate beads under chemical (culture medium supplements) and/or physical (culture in bioreactor) stimuli, providing a tissue-mimetic microenvironment, without prior monoculture differentiation steps [172]. In 2010, for the first time, Jing et al. [185] presented a culture platform for inducing cardiogenic differentiation of both mouse and human embryonic stem cells (ESCs) encapsulated in PLL-coated alginate beads with a liquefied core. This latter morphological feature was indicated as being responsible for enhanced size control of the ESC aggregates, formed within the beads. Moreover, the core was also claimed to have made possible more efficient circulation of paracrine factors inside the beads. This aspect had a beneficial impact on the differentiation of the ESCs and massive production of cardiomyocytes. The configuration and physical/chemical characteristics (e.g. G/M ratio) of the alginate beads thus have a significant influence on the expansion rate of the SCs, as well as on their differentiation and acquisition of a selected phenotype [186, 187]. Stiff alginate beads, presenting high $\mathrm{G}$ residue content, delayed SC growth and inhibited loss of pluripotency; SCs thus remained in an undifferentiated state for longer time periods. Instead, flexible alginate beads, with a high $\mathrm{M}$ residue content, had an impact on the selection of the differentiation path promoting SC phenotypical changes toward the endodermal lineage [188].

Nevertheless, directed differentiation trajectories can be more efficiently modulated by incorporating specific cues into the alginate bead matrix [188]. Depending on the final application, the alginate bead matrix can be functionalized with additional compounds that improve SC adhesion and environment recognition. Hence, theoretically, a single alginate microencapsulation culture system may be enough to induce differentiation of large numbers of distinct differentiated cell lineages, using specific compounds (i.e. growth factors, extracellular matrix proteins, etc.) in the alginate bead matrix. Focaroli et al.[189], for instance, defined a new platform for stimulating chondrogenic differentiation of human adipose-derived mesenchymal stem cells (ADMSCs) within calcium/cobalt alginate beads. The rationale of the study was to chemically reproduce, by adding cobalt, the native hypoxic environment of articular cartilage. The synergic action of cobalt and alginate was evaluated and nevertheless highlighted the favorable impact of the resulting hypoxia-mimicked environment on ADMSC differentiation in cartilage-producing chondrocytes. Song et al. [170] used bone powder, sourced from natural bone and containing hydroxyapatite (HA) and bone morphogenetic proteins, as a signal for promoting osteoinduction and osteogenesis of human ADMSCs encapsulated in alginate beads. Dynamic culture, conducted via spinner flask, was adopted to further enrich the niche-like environment during the osteogenic induction period. This condition made possible accelerated expansion of the SCs, which then readily differentiated into osteoblasts with extensive mineralized nodules forming bone aggregates. The hybrid alginate beads thus presented characteristics that can be considered as promising for tissue- engineered bone substitutes for treating skeletal injuries in future applications.

Overall, incorporated compounds showed great potential in leading SC differentiation, although the role of the alginate beads must be recognized in these circumstances. The alginate beads, in fact, supported SC differentiation without interfering or inhibiting the action undertaken by the incorporated compounds. This aspect was stressed in a recent study. $\mathrm{Ba}^{2+}$ cross-linked alginate beads were prepared with the addition of synthetic octacalcium phosphate (OCP) and used to induce osteoblastic differentiation of encapsulated mouse BMSCs. OCP is a highly osteoconductive material which tends to convert into HA under physiological conditions $[190,191]$. This process enhances bone regeneration [192]. In the study, alginate beads did not inhibit the thermodynamic conversion of the OCP, which could act unconditionally and, thus, it increased the osteoblastic differentiation of the SCs as compared to alginate beads without OCP.

Including peculiar compounds in the alginate bead matrix has also been used to provide the final construct with specific features[193]. Interestingly, Zhang et al. [194] presented an innovative strategy for creating constructs intended for bone regeneration in contaminated sites. Alginate beads were manufactured with dopamine and silver nanoparticles, and encapsulated with mouse bone marrow mesenchymal stem cells (BMSCs). Dopamine (a derivate of DOPA) was incorporated to improve cell adhesion and viability, whereas silver nanoparticles were added to provide the alginate beads with anti-bacterial potential, which is beneficial in case of transplantation into contaminated sites. The results suggested that (i) the anti-bacterial effect was well accomplished, (ii) living BMSCs increased in number, and (iii) underwent osteogenic differentiation, showing increased gene expression and protein production of mineralization.

\subsubsection{In situ Cell Differentiation}

A minority of studies designed the microencapsulation of SCs in alginate beads for in vivo regenerative purposes [172, 195-200]. Most of these studies focused on chondrogenic and osteogenic differentiation of SCs to repair fractures in small-sized animal models. Wang et al. [201], for instance, introduced HA into the structure of the alginate beads for osteoblastic differentiation of human MSCs. The construct was maintained in in vitro culture for about 21 days in order to monitor MSC differentiation in both dynamic and static conditions. In both situations, the inclusion of HA was extremely important for initiating transmission of differentiation signals to the cells. HA inclusion entailed shape changes for the alginate beads and increased their stiffness; these modifications had a beneficial effect on osteoblastic differentiation. The in vitro preformed construct was then implanted into rat femoral condyle defects; this implantation site was chosen as a non-load bearing site as the goal here was to investigate the construct's capacity for osteointegration. Tissue formation in the defect site and recognition of the implant by native cells was made possible thanks to the presence of newlyformed in vitro cell-laid matrix from the differentiated MSCs within the alginate beads. This probably closely mimicked the native bone. The authors thus speculated that the construct may be used as an accurate bone template in critically-sized defects.

The increasing number of studies proves the potential associated with this technology. Alginate beads may thus be an effective alternative tool for the optimal expansion and differentiation of SCs. Moreover, alginate beads may offer the differentiated cells a ready-implantable structure. This platform may therefore be a way of overcoming the shortage of cells needed to engineer bioartificial substitutes for damaged organs, which is the biggest challenge for their clinical applications. There is still a long way to go, however, and there remain many obstacles. A real barrier is put by the lack of defined differentiation protocols. Consequently, the differentiated cells often present low purity and unwanted cells, which could rise 
to tumors; these drawbacks make the differentiated cells inadequate for the actual transplantation [202]. Therefore, the in vitro differentiation pathways should be further investigated and clearly defined in order to obtain specific lines of adult cells with less contamination. Moreover, well-designed induction protocols may be beneficial to solve the problem of low frequency of iPCs. In this manner, iPCs may be directly reprogrammed from the patient's own cells overcoming, thus, the issues of immunorejection and ethics associated with the use of SCs [202].

\section{CONCLUSION}

The aim of the present review was to point out the crucial role of cell microencapsulation technology in the fields of tissue engineering and regenerative medicine as a strategy for treating different diseases, such as diabetes or liver failure. Alginate-based microencapsulation covers a broad spectrum of medical applications beyond those reviewed here. However, the growing number of studies also suggests that supplemental basic analysis (e.g. optimization of alginate parameters in relation to each specific cell type) is needed to concretize its actual contribution in clinical cases. These studies carried out worldwide by different research groups are promising and allow us to believe that real progress will be made in the near future.

\section{CONFLICT OF INTEREST}

None.

\section{ACKNOWLEDGEMENTS}

This work was funded by the EU Marie Curie ITN Project BIOART (grant no.316690, EU-FP7-PEOPLE-ITN-2012) and by Picardie Region (post-doctoral fellowship U. Pereira)

\section{REFERENCES}

[1] Berthiaume F, Maguire TJ, Yarmush ML. Tissue engineering and regenerative medicine: history, progress, and challenges. Ann Rev Chem Biomol Eng 2011; 2: 403-30.

[2] Vacanti JP, Kulig KM. Liver cell therapy and tissue engineering for transplantation. In: ed.^eds., Seminars in pediatric surgery. Elsevier 2014; pp. 150-5.

[3] Basta G, Montanucci P, Luca G, Boselli C, et al. Long-Term metabolic and immunological follow-up of nonimmunosuppressed patients with type 1 diabetes treated with microencapsulated islet allografts four cases. Diabetes Care 2011; 34: 2406-9.

[4] Tuch BE, Keogh GW, Williams LJ, et al. Safety and viability of microencapsulated human islets transplanted into diabetic humans. Diabetes Care 2009; 32: 1887-9.

[5] Gross RE, Watts RL, Hauser RA, et al. Intrastriatal transplantation of microcarrier-bound human retinal pigment epithelial cells versus sham surgery in patients with advanced Parkinson's disease: a double-blind, randomised, controlled trial. Lancet Neurol 2011; 10 : 509-19.

[6] Hasse C, Klöck G, Schlosser A, Zimmermann U, Rothmund M. Parathyroid allotransplantation without immunosuppression. The Lancet 1997; 350: 1296-7.

[7] Löhr M, Hoffmeyer A, Kröger J-C, et al. Microencapsulated cellmediated treatment of inoperable pancreatic carcinoma. The Lancet 2001; 357: 1591-2.

[8] Santos E, Pedraz JL, Hernández RM, Orive G. Therapeutic cell encapsulation: ten steps towards clinical translation. J Controlled Release 2013; 170: 1-14.

[9] de Vos P. Historical perspectives and current challenges in cell microencapsulation. cell microencapsulation: Methods Protocols 2017: 3-21.

[10] Gasperini L, Mano JF, Reis RL. Natural polymers for the microencapsulation of cells. J Royal Soc Interface 2014; 11: 20140817.

[11] Bhujbal SV, de Haan B, Niclou SP, de Vos P. A novel multilayer immunoisolating encapsulation system overcoming protrusion of cells. Sci Rep 2014; 4

[12] De Bartolo L, Bader A, Dufresne M, et al. Microencapsulation and Bioreactors for Liver Support. In: ed.^eds., Biomaterials for Stem
Cell Therapy: State of Art and Vision for the Future. CRC Press 2013; pp. 425-47.

[13] Santos E, Zarate J, Orive G, Hernández RM, Pedraz JL. Biomaterials in cell microencapsulation. In: ed.^eds., Therapeutic applications of cell microencapsulation. Springer 2010; pp. 5-21.

[14] Swioklo S, Connon CJ. Keeping cells in their place: the future of stem cell encapsulation. In: ed.^eds. Taylor Francis 2016.

[15] Murua A, Portero A, Orive G, Hernández RM, de Castro M, Pedraz JL. Cell microencapsulation technology: towards clinical application. J Controlled Release 2008; 132: 76-83.

[16] Lee KY, Mooney DJ. Alginate: properties and biomedical applications. Prog Polym Sci 2012; 37: 106-26.

[17] Remminghorst U, Rehm BH. Bacterial alginates: from biosynthesis to applications. Biotechnol Lett 2006; 28: 1701-12.

[18] George M, Abraham TE. Polyionic hydrocolloids for the intestinal delivery of protein drugs: alginate and chitosan-a review. J Controlled Release 2006; 114: 1-14

[19] Krol S, Del Guerra S, Grupillo M, Diaspro A, Gliozzi A, Marchetti P. Multilayer nanoencapsulation. New approach for immune protection of human pancreatic islets. Nano Lett 2006; 6: 1933-9.

[20] Constantinidis I, Rask I, Long RC, Sambanis A. Effects of alginate composition on the metabolic, secretory, and growth characteristics of entrapped $\beta$ TC3 mouse insulinoma cells. Biomaterials 1999; 20: 2019-27.

[21] Stabler C, Wilks K, Sambanis A, Constantinidis I. The effects of alginate composition on encapsulated $\beta$ TC3 cells. Biomaterials 2001; 22: 1301-10.

[22] Stabler CL, Sambanis A, Constantinidis I. Effects of alginate composition on the growth and overall metabolic activity of $\beta \mathrm{tc} 3$ cells. Ann N York Acad Sci 2002; 961: 130-3.

[23] Simpson NE, Stabler CL, Simpson CP, Sambanis A, Constantinidis I. The role of the $\mathrm{CaCl} 2$-guluronic acid interaction on alginate encapsulated $\beta$ TC3 cells. Biomaterials 2004; 25: 2603-10.

[24] Orive G, Hernández RM, Gascón AR, et al. Cell encapsulation: promise and progress. Nat Med 2003; 9: 104-7.

[25] Klöck G, Frank H, Houben R, et al. Production of purified alginates suitable for use in immunoisolated transplantation. Appl Microbiol Biotechnol 1994; 40: 638-43.

[26] De Vos P, De Haan B, Wolters G, Strubbe J, Van Schilfgaarde R. Improved biocompatibility but limited graft survival after purification of alginate for microencapsulation of pancreatic islets. Diabetologia 1997; 40: 262-70.

[27] Prokop A, Wang TG. Purification of Polymers Used for Fabrication of an Immunoisolation Barriera. Ann N York Acad Sci 1997; 831: 223-31.

[28] Dusseault J, Tam SK, Ménard M, et al. Evaluation of alginate purification methods: effect on polyphenol, endotoxin, and protein contamination. J Biomed Mater Res Part A 2006; 76: 243-51.

[29] Andersen T, Auk-Emblem P, Dornish M. 3D cell culture in alginate hydrogels. Microarrays 2015; 4: 133-61.

[30] Somo SI, Khanna O, Brey EM. Alginate microbeads for cell and protein delivery. Cell Microencapsulation: Methods and Protocols 2017: 217-24.

[31] Ching SH, Bansal N, Bhandari B. Alginate gel particles-a review of production techniques and physical properties. Critic Rev Food Sci Nutr 2015: 00-00.

[32] Velasco D, Tumarkin E, Kumacheva E. Microfluidic encapsulation of cells in polymer microgels. Small 2012; 8: 1633-42.

[33] Chan HF, Zhang Y, Leong KW. Efficient one-step production of microencapsulated hepatocyte spheroids with enhanced functions. Small 2016; 12: 2720-30.

[34] Sharma V, Hunckler M, Ramasubramanian MK, Opara EC, Katuri KC. Microfluidic approach to cell microencapsulation. Cell microencapsulation: Methods and Protocols 2017: 71-6.

[35] Datar A, Joshi P, Lee M-Y. Biocompatible hydrogels for microarray cell printing and encapsulation. Biosensors 2015; 5: 647-63.

[36] Elbert DL, Herbert CB, Hubbell JA. Thin polymer layers formed by polyelectrolyte multilayer techniques on biological surfaces. Langmuir 1999; 15: 5355-62.

[37] De Rosa M, Carteni M, Petillo O, et al. Cationic polyelectrolyte hydrogel fosters fibroblast spreading, proliferation, and extracellular matrix production: Implications for tissue engineering. J Cell Physiol 2004; 198: 133-43. 
[38] Timmermann W, Gassel H-J, Ulrichs K, Zhong R, Thiede A. Organtransplantation in rats and mice: Microsurgical techniques and immunological principles. Springer Sci Business Media 2012.

[39] Diaspro A, Silvano D, Krol S, Cavalleri O, Gliozzi A. Single living cell encapsulation in nano-organized polyelectrolyte shells. Langmuir 2002; 18: 5047-50.

[40] de Haan BJ, Faas MM, de Vos P. Factors influencing insulin secretion from encapsulated islets. Cell Transplant 2003; 12: 61725.

[41] de Vos P, Marchetti P. Encapsulation of pancreatic islets for transplantation in diabetes: the untouchable islets. Trends in molecular medicine 2002; 8: 363-6.

[42] Sambanis A. Encapsulated islets in diabetes treatment. Diabetes Technol Ther 2003; 5: 665-8.

[43] De Groot M, Keizer P, De Haan B, et al. Microcapsules and their ability to protect islets against cytokine-mediated dysfunction. In: ed. ${ }^{\wedge}$ eds., Transplantation proceedings. Elsevier 2001; pp. 1711-2.

[44] Köllmer M, Appel AA, Somo SI, Brey EM. Long-term function of alginate-encapsulated islets. Tissue Eng Part B: Rev 2015; 22: 3446.

[45] Strand BL, Ryan L, Veld PIt, et al. Poly-L-lysine induces fibrosis on alginate microcapsules via the induction of cytokines. Cell Transplant 2001; 10: 263-75.

[46] Soon-Shiong P, Heintz R, Merideth N, et al. Insulin independence in a type 1 diabetic patient after encapsulated islet transplantation. The Lancet 1994; 343: 950-51.

[47] Qi M, Strand BL, Mørch Y, et al. Encapsulation of human islets in novel inhomogeneous alginate- $\mathrm{Ca} 2+/ \mathrm{Ba} 2+$ microbeads: in vitro and in vivo function. Artificial Cells, Blood Substitutes, Biotechnol 2008; 36: 403-20.

[48] Arifin DR, Manek S, Call E, Arepally A, Bulte JW. Microcapsules with intrinsic barium radiopacity for immunoprotection and $\mathrm{X}$ ray/CT imaging of pancreatic islet cells. Biomaterials 2012; 33: 4681-9.

[49] Wikström J, Elomaa M, Nevala L, et al. Viability of freeze dried microencapsulated human retinal pigment epithelial cells. Eur J Pharm Sci 2012; 47: 520-26.

[50] Hall KK, Gattás-Asfura KM, Stabler CL. Microencapsulation of islets within alginate/poly (ethylene glycol) gels cross-linked via Staudinger ligation. Acta Biomater 2011; 7: 614-24.

[51] Mahou R, Tran NM, Dufresne M, Legallais C, Wandrey C. Encapsulation of Huh-7 cells within alginate-poly (ethylene glycol) hybrid microspheres. J Mater Sci 2012; 23: 171-9.

[52] Sun J-Y, Zhao X, Illeperuma WR, et al. Highly stretchable and tough hydrogels. Nature 2012; 489: 133-6.

[53] Bisceglie V. Über die antineoplastische Immunität. J Cancer Res Clin Oncol 1934; 40: 122-40.

[54] Algire GH, Weaver JM, Prehn RT. Growth of cells in vivo in diffusion chambers. I. Survival of Homografts in Immunized Mice2. 1954.

[55] Chang TM. Semipermeable microcapsules. Science 1964; 146: 524-5.

[56] Lim F, Sun AM. Microencapsulated islets as bioartificial endocrine pancreas. Science 1980; 210: 908-10.

[57] McCall M, Shapiro AJ. Update on islet transplantation. Cold Spring Harbor perspectives in medicine 2012; 2: a007823.

[58] Opara EC, McQuilling JP, Farney AC. Microencapsulation of pancreatic islets for use in a bioartificial pancreas. Organ Regeneration: Methods and Protocols 2013: 261-6.

[59] Omer A, Duvivier-Kali V, Fernandes J, Tchipashvili V, Colton CK, Weir GC. Long-term normoglycemia in rats receiving transplants with encapsulated islets. Transplantation 2005; 79: 52-8.

[60] Dufrane D, Goebbels R-M, Saliez A, Guiot Y, Gianello P. Sixmonth survival of microencapsulated pig islets and alginate biocompatibility in primates: proof of concept. Transplantation 2006; 81: 1345-53.

[61] Calafiore R, Basta G, Luca G, et al. Transplantation of pancreatic islets contained in minimal volume microcapsules in diabetic high mammalians. Ann N York Acad Sci 1999; 875: 219-32.

[62] De Vos P, Hamel A, Tatarkiewicz K. Considerations for successful transplantation of encapsulated pancreatic islets. Diabetologia 2002; 45: 159-73.

[63] De Vos P, Smedema I, Van Goor H, et al. Association between macrophage activation and function of micro-encapsulated rat islets. Diabetologia 2003; 46: 666-73.
[64] Goosen MF, O'Shea GM, Gharapetian HM, Chou S, Sun AM. Optimization of microencapsulation parameters: semipermeable microcapsules as a bioartificial pancreas. Biotechnology and bioengineering $1985 ; 27$ : 146-50.

[65] Sun A, O'Shea G. Transplantation of microencapsulated islets of Langerhans as an insulin delivery system. Topics in pharmaceutical sciences 1985: 93-100.

[66] Sun AM, O'shea GM, Goosen MF. Injectable microencapsulated islet cells as a bioartificial pancreas. In: ed.^eds., Microencapsulation and Artificial Cells. Springer 1984; pp. 87-99.

[67] Chen CF, Chern HT, Ieu FJ, Chang TM, Shian LR, Sun AM. Xenotransplantation of microencapsulated canine islets into diabetic rats. Artificial organs 1994; 18: 193-7.

[68] Ricker A, Stockberger S, Halban P, Eisenbarth GS, Bonner-Weir S. Hyperimmune response to microencapsulated xenogeneic tissue in non-obese diabetic mice. The Immunology of Diabetes Mellitus. Amsterdam, Elsevier 1986; 193.

[69] Bhujbal SV, Paredes-Juarez GA, Niclou SP, de Vos P. Factors influencing the mechanical stability of alginate beads applicable for immunoisolation of mammalian cells. J mechanical behavior of biomedical materials 2014; 37: 196-208.

[70] Dufrane D, van Steenberghe M, Goebbels R-M, Saliez A, Guiot Y, Gianello P. The influence of implantation site on the biocompatibility and survival of alginate encapsulated pig islets in rats. Biomaterials 2006; 27: 3201-08.

[71] Chaimov D, Baruch L, Krishtul S, Meivar-Levy I, Ferber S, Machluf M. Innovative encapsulation platform based on pancreatic extracellular matrix achieve substantial insulin delivery. J Controlled Release 2016.

[72] King A, Lau J, Nordin A, Sandler S, Andersson A. The effect of capsule composition in the reversal of hyperglycemia in diabetic mice transplanted with microencapsulated allogeneic islets. Diabetes Technol Ther 2003; 5: 653-63.

[73] Ponce S, Orive G, Hernández R, et al. Chemistry and the biological response against immunoisolating alginate-polycation capsules of different composition. Biomaterials 2006; 27: 4831-9.

[74] Duvivier-Kali VF, Omer A, Parent RJ, O’Neil JJ, Weir GC. Complete protection of islets against allorejection and autoimmunity by a simple barium-alginate membrane. Diabetes 2001; 50: 1698-705.

[75] Thu B, Bruheim P, Espevik T, Smidsrød O, Soon-Shiong P, SkjåkBræk G. Alginate polycation microcapsules: II. Some functional properties. Biomaterials 1996; 17: 1069-79.

[76] Benson J, Papas KK, Constantinidis I, Sambanis A. Towards the development of a bioartificial pancreas: effects of poly-L-lysine on alginate beads with BTC3 cells. Cell Transplant 1997; 6: 395-402.

[77] Rokstad AM, Donati I, Borgogna M, et al. Cell-compatible covalently reinforced beads obtained from a chemoenzymatically engineered alginate. Biomaterials 2006; 27: 4726-37.

[78] Jeon O, Bouhadir KH, Mansour JM, Alsberg E. Photocrosslinked alginate hydrogels with tunable biodegradation rates and mechanical properties. Biomaterials 2009; 30: 2724-34.

[79] Dusseault J, Leblond FA, Robitaille R, et al. Microencapsulation of living cells in semi-permeable membranes with covalently crosslinked layers. Biomaterials 2005; 26: 1515-22.

[80] Lu M, Lan H, Wang F, Chang S, Wang Y. Cell encapsulation with alginate and $\alpha$-phenoxycinnamylidene-acetylated poly (allylamine). Biotechnology and bioengineering 2000; 70: 479-83.

[81] Desai N, Sojomihardjo A, Yao Z, Ron N, Soon-Shiong P. Interpenetrating polymer networks of alginate and polyethylene glycol for encapsulation of islets of Langerhans. J Microencapsulation 2000; 17: 677-90.

[82] Chen H, Ouyang W, Jones $\mathrm{M}$, et al. Preparation and characterization of novel polymeric microcapsules for live cell encapsulation and therapy. Cell Biochem Biophys 2007; 47: 15967.

[83] Breguet V, Gugerli R, Pernetti M, Von Stockar U, Marison IW. Formation of microcapsules from polyelectrolyte and covalent interactions. Langmuir 2005; 21: 9764-72.

[84] Wang MS, Childs RF, Chang PL. A novel method to enhance the stability of alginate-poly-L-lysine-alginate microcapsules. J Biomater Sci Polym Edt 2005; 16: 89-111.

[85] Birnbaum S, Pendleton R, Larsson P-O, Mosbach K. Covalent stabilization of alginate gel for the entrapment of living whole cells. Biotechnol Lett 1981; 3: 393-400. 
[86] Hals IK, Rokstad AM, Strand BL, Oberholzer J, Grill V. Alginate microencapsulation of human islets does not increase susceptibility to acute hypoxia. J Diabetes Res 2013; 2013.

[87] Scharp DW, Marchetti P. Encapsulated islets for diabetes therapy: history, current progress, and critical issues requiring solution. Adv Drug Deliv Rev 2014; 67: 35-73.

[88] Wang T, Adcock J, Kühtreiber W, et al. Successful allotransplantation of encapsulated islets in pancreatectomized canines for diabetic management without the use of immunosuppression. Transplantation 2008; 85: 331-7.

[89] Elliott R, Escobar L, Calafiore R, et al. Transplantation of microand macroencapsulated piglet islets into mice and monkeys. In: ed. ^eds., Transplantation proceedings. Elsevier 2005; pp. 466-9.

[90] Mazzitelli S, Tosi A, Balestra C, et al. Production and characterization of alginate microcapsules produced by a vibrational encapsulation device. J Biomater Appl 2008.

[91] Luca G, Calvitti M, Neri L, et al. Sertoli cell-induced reversal of adult rat pancreatic islet beta-cells into fetal-like status: potential implications for islet transplantation in type I diabetes mellitus. J investigative medicine: the official publication of the American Federation for Clinical Res 2000; 48: 441-8.

[92] Calafiore R, Basta G, Luca G, et al. Standard technical procedures for microencapsulation of human islets for graft into nonimmunosuppressed patients with type 1 diabetes mellitus. In: ed.^eds., Transplantation proceedings. Elsevier 2006; pp. 1156-7.

[93] O'sullivan E, Johnson A, Omer A, Hollister-Lock J, Bonner-Weir $\mathrm{S}$, Colton C, Weir G. Rat islet cell aggregates are superior to islets for transplantation in microcapsules. Diabetologia 2010; 53: 93745.

[94] Elliott R, Escobar L, Tan P, et al. Intraperitoneal alginateencapsulated neonatal porcine islets in a placebo-controlled study with 16 diabetic cynomolgus primates. In: ed.^eds., Transplantation proceedings. Elsevier 2005; pp. 3505-8.

[95] Kerby A, Bohman S, Westberg H, Jones P, King A. Immunoisolation of islets in high guluronic acid barium-alginate microcapsules does not improve graft outcome at the subcutaneous site. Artificial organs 2012; 36: 564-70.

[96] Pileggi A, Molano RD, Ricordi C, et al. Reversal of diabetes by pancreatic islet transplantation into a subcutaneous, neovascularized device. Transplantation 2006; 81: 1318-24.

[97] Lacy PE, Hegre OD, Gerasimidi-Vazeou A, Gentile FT, Dionne KE. Maintenance of normoglycemia in diabetic mice by subcutaneous xenografts of encapsulated islets. Science 1991; 254: $1782-4$.

[98] Tatarkiewicz K, Hollister-Lock J, Quickel RR, Colton CK, BonnerWeir S, Weir GC. Reversal of hyperglycemia in mice after subcutaneous transplantation of macroencapsulated islets. Transplantation 1999; 67: 665-71.

[99] Bohman S, Andersson A, King A. No differences in efficacy between noncultured and cultured islets in reducing hyperglycemia in a nonvascularized islet graft model. Diabetes Technol Ther 2006; 8: 536-45.

[100] Bohman S, King AJ. Islet alpha cell number is maintained in microencapsulated islet transplantation. Biochem Biophys Res Commun 2008; 377: 729-33.

[101] Calafiore R, Basta G, Luca G, et al. Microencapsulated pancreatic islet allografts into nonimmunosuppressed patients with type 1 diabetes first two cases. Diabetes Care 2006; 29: 137-8.

[102] Calafiore R, Basta G. Clinical application of microencapsulated islets: actual prospectives on progress and challenges. Adv Drug Deliv Rev 2014; 67: 84-92.

[103] Elliott RB, Escobar L, Tan PL, Muzina M, Zwain S, Buchanan C. Live encapsulated porcine islets from a type 1 diabetic patient 9.5 yr after xenotransplantation. Xenotransplantation 2007; 14: 157-61.

[104] Jacobs-Tulleneers-Thevissen D, Chintinne M, Ling Z, et al. Sustained function of alginate-encapsulated human islet cell implants in the peritoneal cavity of mice leading to a pilot study in a type 1 diabetic patient. Diabetologia 2013; 56: 1605-14.

[105] Dixit V, Arthur M, Reinhardt R, Gitnick G. Improved function of microencapsulated hepatocytes in a hybrid bioartificial liver support system. Artificial organs 1992; 16:336-41.

[106] Guyomard C, Rialland L, Fremond B, Chesne C, Guillouzo A. Influence of alginate gel entrapment and cryopreservation on survival and xenobiotic metabolism capacity of rat hepatocytes. Toxicol Appl Pharmacol 1996; 141: 349-56.
[107] Kim S-P, Lee D-H, Park J-K. Development of hepatocyte spheroids immobilization technique using alternative encapsulation method. Biotechnology and Bioprocess Engineering 1998; 3: 96-102.

[108] Falasca L, Miccheli A, Sartori E, Tomassini A, Conti Devirgiliis L. Hepatocytes entrapped in alginate gel beads and cultured in bioreactor: rapid repolarization and reconstitution of adhesion areas. Cells Tissues Organs 2001; 168: 126-36.

[109] Gao Y, Xu J, Sun B, Jiang H-C. Microencapsulated hepatocytes and islets as in vivo bioartificial liver support system. World J Gastroenterol 2004; 10: 2067-71.

[110] Gao Y, Jiang H, Xu J, Pan S, Li Y. Microencapsulating hepatocytes. In: ed.^eds., Transplantation proceedings. Elsevier 2005; pp. 4589-93.

[111] Quek C-H, Li J, Sun T, et al. Photo-crosslinkable microcapsules formed by polyelectrolyte copolymer and modified collagen for rat hepatocyte encapsulation. Biomaterials 2004; 25: 3531-40.

[112] Murtas S, Capuani G, Dentini M, et al. Alginate beads as immobilization matrix for hepatocytes perfused in a bioreactor: a physico-chemical characterization. J Biomater Sci Polym Edt 2005; 16: 829-46.

[113] Teng Y, Wang Y, Li S, et al. Treatment of acute hepatic failure in mice by transplantation of mixed microencapsulation of rat hepatocytes and transgenic human fetal liver stromal cells. Tissue Engineering Part C: Methods 2010; 16: 1125-34.

[114] Aoki T, Jin Z, Nishino N, et al. Intrasplenic transplantation of encapsulated hepatocytes decreases mortality and improves liver functions in fulminant hepatic failure from $90 \%$ partial hepatectomy in rats. Transplantation 2005; 79: 783-90.

[115] Ringel M, Von Mach M, Santos R, et al. Hepatocytes cultured in alginate microspheres: an optimized technique to study enzyme induction. Toxicology 2005; 206: 153-67.

[116] Mai G, Huy NT, Morel P, et al. Treatment of fulminant liver failure by transplantation of microencapsulated primary or immortalized xenogeneic hepatocytes. Xenotransplantation 2005; 12: 457-64.

[117] Diekmann S, Glöckner P, Bader A. The influence of different cultivation conditions on the metabolic functionality of encapsulated primary hepatocytes. Int J Artificial Organs 2007; 30: 192-8.

[118] Shi XL, Zhang Y, Gu JY, Ding YT. Coencapsulation of hepatocytes with bone marrow mesenchymal stem cells improves hepatocyte-specific functions. Transplantation 2009; 88: 1178-85.

[119] Miranda JP, Rodrigues A, Tostoes RM, et al. Extending hepatocyte functionality for drug-testing applications using high-viscosity alginate-encapsulated three-dimensional cultures in bioreactors. Tissue Engineering Part C: Methods 2010; 16: 1223-32.

[120] Tostoes RM, Leite SB, Miranda JP, et al. Perfusion of 3D encapsulated hepatocytes-A synergistic effect enhancing long-term functionality in bioreactors. Biotechnol Bioeng 2011; 108: 41-9.

[121] Hwang Y, Kim Y, Lee J, Lee J, Kim J, Chung J. Development of bioartificial liver system using a fluidized-bed bioreactor. In: ed.^eds., Transplantation proceedings. Elsevier 2000; pp. 2349-51.

[122] Lv G, Zhao L, Zhang A, et al. Bioartificial liver system based on choanoid fluidized bed bioreactor improve the survival time of fulminant hepatic failure pigs. Biotechnol Bioeng 2011; 108: 222936.

[123] Desille M, Fremond B, Mahler S, et al. Improvement of the neurological status of pigs with acute liver failure by hepatocytes immobilized in alginate gel beads inoculated in an extracorporeal bioartificial liver. In: ed.^eds., Transplantation proceedings. Elsevier 2001; pp. 1932-34.

[124] Desille M, Mahler S, Seguin P, et al. Reduced encephalopathy in pigs with ischemia-induced acute hepatic failure treated with a bioartificial liver containing alginate-entrapped hepatocytes. Critic Care Med 2002; 30: 658-63.

[125] Mei J, Sgroi A, Mai G, et al. Improved survival of fulminant liver failure by transplantation of microencapsulated cryopreserved porcine hepatocytes in mice. Cell Transplant 2009; 18: 101-10.

[126] Selden C, Khalil M, Hodgson H. Three dimensional culture upregulates extracellular matrix protein expression in human liver cell lines--a step towards mimicking the liver in vivo? Int $\mathrm{J}$ Artificial Organs 2000; 23: 774-81.

[127] David B, Dufresne M, Nagel MD, Legallais C. In vitro assessment of encapsulated C3A hepatocytes functions in a fluidized bed bioreactor. Biotechnol Prog 2004; 20: 1204-12. 
[128] Rahman TM, Diakanov I, Selden C, Hodgson H. Co-transplantation of encapsulated HepG2 and rat Sertoli cells improves outcome in a thioacetamide induced rat model of acute hepatic failure. Transplant Int 2005; 18: 1001-9.

[129] Haque $\mathrm{T}$, Chen $\mathrm{H}$, Ouyang $\mathrm{W}$, et al. Investigation of a new microcapsule membrane combining alginate, chitosan, polyethylene glycol and poly-L-lysine for cell transplantation applications. Int J Artificial Organs 2005; 28: 631-7.

[130] Kinasiewicz A, Gautier A, Lewinska D, Bukowski J, Legallais C, Weryński A. Culture of C3A cells in alginate beads for fluidized bed bioartificial liver. In: ed.^eds., Transplantation proceedings. Elsevier 2007; pp. 2911-13.

[131] Gautier A, Carpentier B, Dufresne M, Vu Dinh Q, Paullier P, Legallais $C$. Impact of alginate type and bead diameter on mass transfers and the metabolic activities of encapsulated C3A cells in bioartificial liver applications. Eur Cell Mater 2011; 21: 94-106.

[132] Coward SM, Selden C, Mantalaris A, Hodgson HJ. Proliferation rates of HepG2 cells encapsulated in alginate are increased in a microgravity environment compared with static cultures. Artificial Organs 2005; 29: 152-8.

[133] Coward SM, Legallais C, David B, et al. Alginate-encapsulated HepG2 cells in a fluidized bed bioreactor maintain function in human liver failure plasma. Artificial organs 2009; 33: 1117-26.

[134] Lee KH, Kim S-H, Ryoo JH, Wong SF, Lee S-H. Diffusionmediated in situ alginate encapsulation of cell spheroids using microscale concave well and nanoporous membrane. Lab on a Chip 2011; 11: 1168-73.

[135] Tran NM, Dufresne M, Duverlie G, et al. An appropriate selection of a 3D alginate culture model for hepatic Huh-7 cell line encapsulation intended for viral studies. Tissue engineering Part A 2012; 19: 103-13.

[136] Tran N-M, Dufresne M, Helle F, et al. Alginate hydrogel protects encapsulated hepatic HuH-7 cells against hepatitis $\mathrm{C}$ virus and other viral infections. PloS one 2014; 9: e109969.

[137] Capone SH, Dufresne M, Rechel M, et al. Impact of alginate composition: from bead mechanical properties to encapsulated HepG2/C3A cell activities for in vivo implantation. PloS one 2013; 8: e62032.

[138] Figaro S, Pereira U, Dumé A, et al. SUPPLIVER: Bioartificial supply for liver failure. IRBM 2015; 36: 101-9.

[139] Hang H, Shi X, Wu Y, Gu J, Ding Y. In vitro analysis of cryopreserved alginate-poly-1-lysine-alginate-microencapsulated human hepatocytes. Liver International 2010; 30: 611-22.

[140] Sgroi A, Mai G, Morel P, et al. Transplantation of encapsulated hepatocytes during acute liver failure improves survival without stimulating native liver regeneration. Cell Transplant 2011; 20: 1791-803.

[141] Hughes RD, Mitry RR, Dhawan A. Current status of hepatocyte transplantation. Transplantation 2012; 93: 342-7.

[142] Jitraruch S, Dhawan A, Hughes RD, et al. Alginate microencapsulated hepatocytes optimised for transplantation in acute liver failure. PloS one 2014; 9: e113609.

[143] Canaple L, Nurdin N, Angelova N, Hunkeler D, Desvergne B. Development of a coculture model of encapsulated cells. Ann N York Acad Sci 2001; 944: 350-61.

[144] Jeong GS, Lee S-H. Immune-protected xenogeneic bioartificial livers with liver-specific microarchitecture and hydrogelencapsulated cells. Biomaterials 2014; 35: 8983-8991.

[145] Carpentier B, Gautier A, Legallais C. Artificial and bioartificial liver devices: present and future. Gut 2009; 58: 1690-702.

[146] Struecker B, Raschzok N, Sauer IM. Liver support strategies: cutting-edge technologies. Nat Rev Gastroenterol Hepatol 2014; 11: 166-76.

[147] Doré E, Legallais C. A new concept of bioartificial liver based on a fluidized bed bioreactor. Ther Apheresis 1999; 3: 264-7.

[148] Legallais C, Doré E, Paullier P. Design of a fluidized bed bioartificial liver. Artificial Organs 2000; 24: 519-25.

[149] Selden C, Spearman CW, Kahn D, et al. Evaluation of encapsulated liver cell spheroids in a fluidised-bed bioartificial liver for treatment of ischaemic acute liver failure in pigs in a translational setting. PloS one 2013; 8: e82312.

[150] Bonavita AG, Quaresma K, Cotta-de-Almeida V, Pinto MA, Saraiva RM, Alves LA. Hepatocyte xenotransplantation for treating liver disease. Xenotransplantation 2010; 17: 181-7.

[151] Dixit V, Darvasi R, Arthur M, Brezina M, Lewin K, Gitnick G. Restoration of liver function in Gunn rats without immunosuppression using transplanted microencapsulated hepatocytes. Hepatology 1990; 12: 1342-9.

[152] Wong H, Chang T. Bioartificial liver: implanted artificial cells microencapsulated living hepatocytes increases survival of liver failure rats. Int J Artificial Organs 1986; 9: 335-6.

[153] Liu ZC, Chang TMS. Coencapsulation of hepatocytes and bone marrow cells: in vitro and in vivo studies. Biotechnol Ann Rev 2006; 12: 137-51.

[154] Liu Z, Chang T. Coencapsulation of hepatocytes and bone marrow stem cells: in vitro conversion of ammonia and in vivo lowering of bilirubin in hyperbilirubemia Gunn rats. Int J Artificial Organs 2003; 26: 491-7.

[155] Orive G, Tam SK, Pedraz JL, Hallé JP. Biocompatibility of alginate-poly-l-lysine microcapsules for cell therapy. Biomaterials 2006; 27: 3691-700.

[156] Chen AA, Thomas DK, Ong LL, Schwartz RE, Golub TR, Bhatia SN. Humanized mice with ectopic artificial liver tissues. Proc Nat Acad Sci 2011; 108: 11842-47.

[157] Chin MH, Mason MJ, Xie W, et al. Induced pluripotent stem cells and embryonic stem cells are distinguished by gene expression signatures. Cell stem cell 2009; 5: 111-23.

[158] Kern S, Eichler H, Stoeve J, Klüter H, Bieback K. Comparative analysis of mesenchymal stem cells from bone marrow, umbilical cord blood, or adipose tissue. Stem cells 2006; 24: 1294-301.

[159] Nadig RR. Stem cell therapy-Hype or hope? A review. J Conservative Dentistry 2009; 12: 131.

[160] Sylvester KG, Longaker MT. Stem cells: review and update. Archives of surgery 2004; 139: 93-9.

[161] Takahashi K, Yamanaka S. Induction of pluripotent stem cells from mouse embryonic and adult fibroblast cultures by defined factors. cell 2006; 126: 663-76.

[162] Wilson KD, Wu JC. Induced pluripotent stem cells. JAMA 2015; 313: 1613-14.

[163] Burdick JA, Vunjak-Novakovic G. Engineered microenvironments for controlled stem cell differentiation. Tissue Engineering Part A 2008; 15: 205-19.

[164] Li Y, Zhou J, Yang X, Jiang Y, Gui J. Intermittent hydrostatic pressure maintains and enhances the chondrogenic differentiation of cartilage progenitor cells cultivated in alginate beads. Develop Growth Differentiation 2016.

[165] Penick KJ, Solchaga LA, Welter JF. High-throughput aggregate culture system to assess the chondrogenic potential of mesenchymal stem cells. Biotechniques 2005; 39: 687.

[166] Dashtdar H, Murali MR, Selvaratnam L, et al. Ultra-structural changes and expression of chondrogenic and hypertrophic genes during chondrogenic differentiation of mesenchymal stromal cells in alginate beads. PeerJ 2016; 4: e1650.

[167] Magyar JP, Nemir M, Ehler E, Suter N, PERRIARD JC, Eppenberger HM. Mass production of embryoid bodies in microbeads. Ann N York Acad Sci 2001; 944: 135-43.

[168] Rohani L, Karbalaie K, Vahdati A, Hatami M, Nasr-Esfahani M, Baharvand H. Embryonic stem cell sphere: a controlled method for production of mouse embryonic stem cell aggregates for differentiation. International J Artificial Organs 2008;31: 258.

[169] Ma HL, Hung SC, Lin SY, Chen YL, Lo WH. Chondrogenesis of human mesenchymal stem cells encapsulated in alginate beads. J Biomed Mater Res Part A 2003; 64: 273-81.

[170] Song K, Yang Y, Xu L, et al. Fabrication and detection of tissue engineered bone aggregates based on encapsulated human ADSCs within hybrid calcium alginate/bone powder gel-beads in a spinner flask. Mate Sci Eng 2016; 62: 787-94.

[171] Xu F, Xu L, Wang Q, Ye Z, Zhou Y, Tan WS. 3D dynamic culture of rabbit articular chondrocytes encapsulated in alginate gel beads using spinner flasks for cartilage tissue regeneration. BioMed Res Int 2014; 2014

[172] Paul A, Ge Y, Prakash S, Shum-Tim D. Microencapsulated stem cells for tissue repairing: implications in cell-based myocardial therapy. Regenerative Med 2009; 4: 733-45.

[173] Li L, Davidovich AE, Schloss JM, et al. Neural lineage differentiation of embryonic stem cells within alginate microbeads. Biomaterials 2011; 32: 4489-97.

[174] Guo T, Yu L, Lim CG, et al. Effect of dynamic culture and periodic compression on human mesenchymal stem cell proliferation and chondrogenesis. Ann Biomed Eng 2015: 1-11. 
[175] Maguire T, Davidovich AE, Wallenstein EJ, et al. Control of hepatic differentiation via cellular aggregation in an alginate microenvironment. Biotechnol Bioeng 2007; 98: 631-44.

[176] Komatsu M, Konagaya S, Egawa EY, Iwata H. Maturation of human iPS cell-derived dopamine neuron precursors in alginate-Ca $2+$ hydrogel. Biochimica et Biophysica Acta (BBA)-General Subjects 2015; 1850: 1669-75.

[177] Bozza A, Coates EE, Incitti T, et al. Neural differentiation of pluripotent cells in 3D alginate-based cultures. Biomaterials 2014; 35: 4636-45.

[178] Wang N, Adams G, Buttery L, Falcone FH, Stolnik S. Alginate encapsulation technology supports embryonic stem cells differentiation into insulin-producing cells. J Biotechnol 2009; 144 : 304-12.

[179] Hwang YS, Cho J, Tay F, et al. The use of murine embryonic stem cells, alginate encapsulation, and rotary microgravity bioreactor in bone tissue engineering. Biomaterials 2009; 30: 499-507.

[180] Yang Z, Huang CY, Candiotti KA, et al. Sox-9 facilitates differentiation of adipose tissue-derived stem cells into a chondrocyte-like phenotype in vitro. J Orthopaedic Res 2011; 29: 1291-7.

[181] Eslaminejad MB, Taghiyar L, Falahi F. Quantitative analysis of the proliferation and differentiation of rat articular chondrocytes in alginate 3D culture. Iranian Biomed J 2009; 13: 153.

[182] Chang JC, Hsu SH, Chen DC. The promotion of chondrogenesis in adipose-derived adult stem cells by an RGD-chimeric protein in $3 \mathrm{D}$ alginate culture. Biomaterials 2009; 30: 6265-75.

[183] Shen B, Wei A, Tao H, Diwan AD, Ma DD. BMP-2 Enhances TGF- 33 -mediated chondrogenic differentiation of human bone marrow multipotent mesenchymal stromal cells in alginate bead culture. Tissue Engineering Part A 2008; 15: 1311-20.

[184] Li X, Liu T, Song K, et al. Culture of neural stem cells in calcium alginate beads. Biotechnol Prog 2006; 22: 1683-9.

[185] Jing D, Parikh A, Tzanakakis ES. Cardiac cell generation from encapsulated embryonic stem cells in static and scalable culture systems. Cell Transplant 2010; 19: 1397-412.

[186] Wang X, Wang W, Ma J, Guo X, Yu X, Ma X. Proliferation and differentiation of mouse embryonic stem cells in APA microcapsule: A model for studying the interaction between stem cells and their niche. Biotechnol Prog 2006; 22: 791-800.

[187] Siti-Ismail N, Bishop AE, Polak JM, Mantalaris A. The benefit of human embryonic stem cell encapsulation for prolonged feederfree maintenance. Biomaterials 2008; 29: 3946-52.

[188] Wilson JL, Najia MA, Saeed R, McDevitt TC. Alginate encapsulation parameters influence the differentiation of microencapsulated embryonic stem cell aggregates. Biotechnol Bioeng 2014; 111: 618-31.
[189] Focaroli S, Teti G, Salvatore V, Orienti I, Falconi M. Calcium/Cobalt alginate beads as functional scaffolds for cartilage tissue engineering. Stem Cell Int 2016; 2016.

[190] Brown W, Mathew M, Tung M. Crystal chemistry of octacalcium phosphate. Prog Crystal Growth Characterization 1981; 4: 59-87.

[191] LeGeros R, Daculsi G, Orly I, Abergas T, Torres W. Solutionmediated transformation of octacalcium phosphate (OCP) to apatite. Scanning microscopy 1989; 3: 129-37; discussion 137-8.

[192] Suzuki O, Kamakura S, Katagiri T, et al. Bone formation enhanced by implanted octacalcium phosphate involving conversion into $\mathrm{Ca}$ deficient hydroxyapatite. Biomaterials 2006; 27: 2671-81.

[193] Hou T, Xu J, Li Q, Feng J, Zen L. In vitro evaluation of a fibrin gel antibiotic delivery system containing mesenchymal stem cells and vancomycin alginate beads for treating bone infections and facilitating bone formation. Tissue Engineering Part A 2008; 14 : 1173-82.

[194] Zhang S, Xu K, Darabi MA, Yuan Q, Xing M. Mussel-inspired alginate gel promoting the osteogenic differentiation of mesenchymal stem cells and anti-infection. Mate Sci Eng 2016; 69: 496-504.

[195] Chen YP, Chen WC, Wang KC, Chen CH. Effectiveness of synovial fluid mesenchymal stem cells embedded in alginate beads for treatment of steroid-induced avascular necrosis of the femoral head. J Orthopaedic Sci 2014; 19: 657-66.

[196] Duval E, Baugé C, Andriamanalijaona R, et al. Molecular mechanism of hypoxia-induced chondrogenesis and its application in in vivo cartilage tissue engineering. Biomaterials 2012;33. 6042-51.

[197] Matsuno T, Hashimoto Y, Adachi S, et al. Preparation of injectable 3D-formed. BETA.-tricalcium phosphate bead/alginate composite for bone tissue engineering. Dental Mater J 2008; 27: 827-34.

[198] Hashimoto Y, Adachi S, Matsuno T, et al. Effect of an injectable 3D scaffold for osteoblast differentiation depends on bead size. Bio-Med Mater Eng 2009; 19: 391-400.

[199] Perrot P, Heymann D, Charrier C, Couillaud S, Rédini F, Duteille F. Extraosseous bone formation obtained by association of mesenchymal stem cells with a periosteal flap in the rat. Annals Plastic Surg 2007; 59: 201-6.

[200] Ueng SW, Lee MS, Lin SS, Chan EC, Liu SJ. Development of a biodegradable alginate carrier system for antibiotics and bone cells. J Orthopaedic Res 2007; 25: 62-72.

[201] Wang MO, Bracaglia L, Thompson JA, Fisher JP. Hydroxyapatite-doped alginate beads as scaffolds for the osteoblastic differentiation of mesenchymal stem cells. J Biomed Mater Res Part A 2016.

[202] Ikehara S. Grand challenges in stem cell treatments. Frontiers Cell Develop Biol 2013; 1: 2 